\title{
Mycodiversity at Sankarnagar Community Forest, Rupandehi District
}

\author{
Hari Prasad Aryal ${ }^{1}$ and Usha Budhathoki ${ }^{2}$ \\ ${ }^{1}$ Paklihawa Campus, Institute of Agriculture and Animal Science, Tribhuvan University \\ ${ }^{2}$ Central Department of Botany, Tribhuvan University, Kathmandu \\ e-mail: hahariprasadaryal06@gmail.com
}

\begin{abstract}
This investigation explored the diversity of higher fungi with their identification, documentation and utilization. The study area covered 549 ha, which lies within a narrow limit of altitude between 165 and 200 masl, in tropical deciduous riverine forest. Amanita chepangiana, A. pantherina, Macrolepiota fuliginosa, M. rhacodes, Russula emetica, $R$. foetens, $R$. nigricans, Scleroderma citrinum, $S$, bovista, Termitomyces clypeatus and T. eurhizeus were found to be dominant. The collected samples represented 29 species of Basidiomycetes belonging to 7 orders, 18 families and 25 genera. The dried specimens housed at Tribhuvan University Central Herbarium (TUCH), Kirtipur, Kathmandu. The mycoelements prevailing in this area need sustainable conservation and utilization.
\end{abstract}

Kew words: basidiomycetes, macrofungi, mushroom diversity

\section{Introduction}

Higher fungi generally contain two main groups, the Ascomycota and Basidiomycota. Although most of the Ascomycota are microscopic species, they also contains some larger fungi such as cup-fungi, morels and truffles. Around 14000 to 16000 species of Basidiomycota are known in the world (Hawksworth et al. 1995, Watkinson et al. 2000). Fungi in the order Agaricales are commonly called mushrooms, toadstools, gill fungi, or agarics. They are also referred to as being terrestrial, lignicolous, saprobic or mycorrhizal. Mushrooms form large fruiting bodies visible without the aid of a microscope. The distribution of macro-fungal species is low in hot and dry seasons while they are abundant in spring and autumn due to humid climate as well as the richness of the flora at this time (Sibounnavong 2008). Macro-fungal studies have long been of interest to scientists in the world for their significant roles in forest ecosystem, human life, their use in the pharmaceutical industry, and the mass production of cultivated fungi in the food industry, as well as their vital role in biodegradation (De Boer et al. 2005). Many studies have reported that the Basidiomycota account for most of the lignocelluloses decomposition in leaf litter (Miyamoto et al. 2000).

Nepal is considered as the homeland for the mushroom floral diversity (Aryal \& Budhathoki 2012). So far 812 mushroom species have been identified (Adhikari 2009). Of them, 228 edible (Christensen et al. 2008), 66 poisonous (Pandey 2008, Adhikari 2009) and 75 medicinal species (Adhikari 2009) have been reported. The investigation on mushrooms of Nepal started since the contribution of (Lloyd 1808, Berkeley 1838), since then several papers have been published and several botanical investigations have been done. Among these, very few reveal the studies and investigation on wild mushrooms from western Nepal. This area has not been investigated so far. This is a preliminary report on mycodiversity investigation carried out at Sankarnagar community forest, Rupandehi district. The paper highlights the study on collection, identification and documentation of wild edible mushrooms in this district. 
The study site is rich in mushroom diversity and offers immense scope for macrofungi studies. The useful wild mushrooms and their ethno-information are being eroded as a result of degradation of appropriate habitat of the species, unsustainable land use activities and over-exploitation of natural resources.

\section{Study area}

The study area lies in Lumbini zone, Rupandehi district, Sankarnagar V. D. C., ward No. 9, in the western
Terai belt of Nepal ((fig. 1). The forest vegetation is dominated by the species of Dipterocarpaceae, Combretaceae and Leguminosae families. The study site is situated between $27.66703^{\circ}-27.68745^{\circ}$ $\mathrm{N}$ latitudes and $83.25137^{\circ}-83.32187^{\circ} \mathrm{E}$ longitudes and an area of 549 ha of forest. The altitude range varies between 165 metre and 200 metre mean above sea level and average annual rainfall is $1391 \mathrm{~mm}$ (DHM 2010).

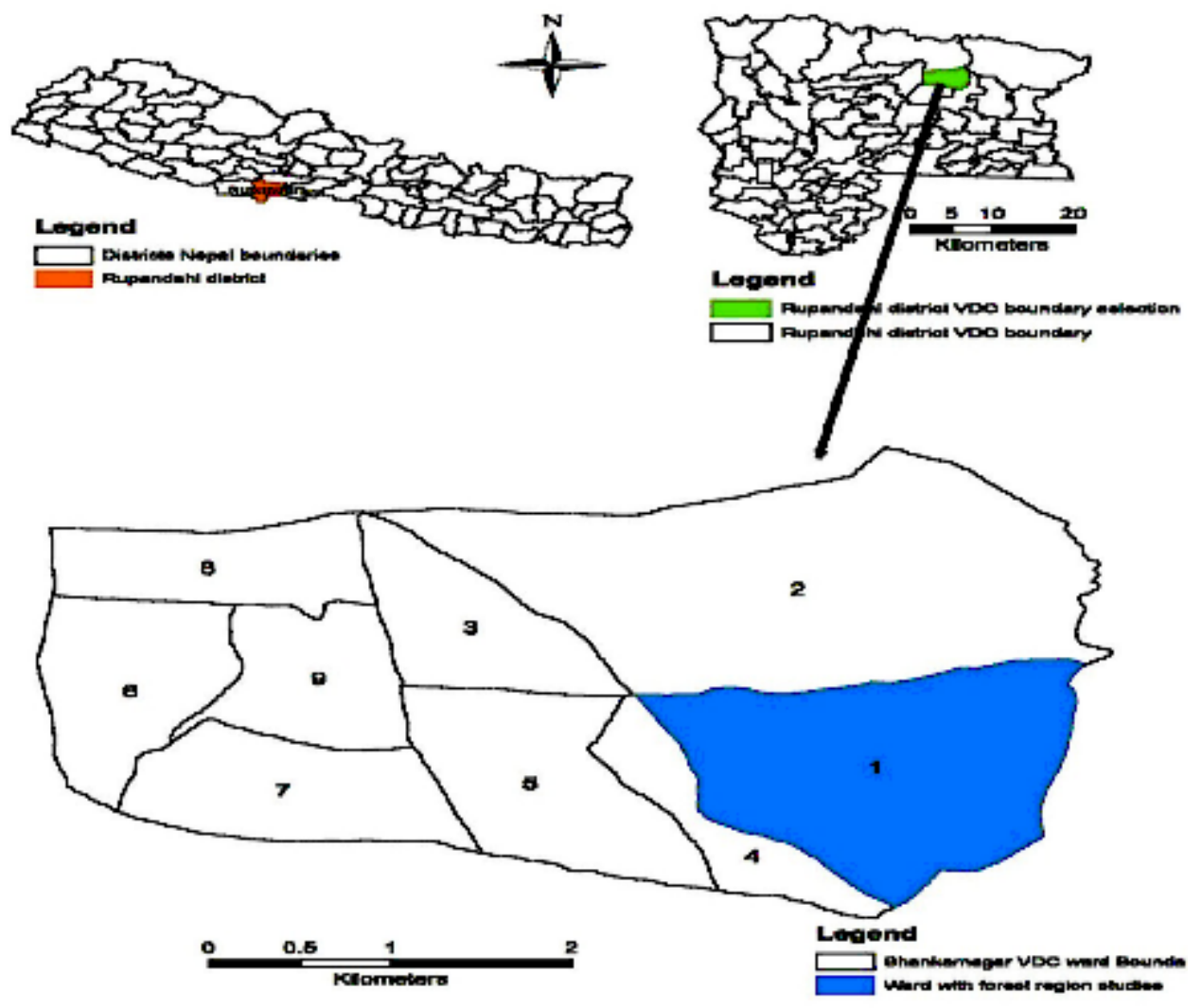

The area lies in the tropical zone embracing different types of vegetation and soil composition. The tropical riverine belt consists of mostly the following vascular flora: Acacia cateachu, Adina cordifolia, Anogeissus latifolius, Bombax ceiba, Dalbergia latifolia, Dalbergia sissoo, Eugeina jambolana, Mallotus philippensis, Phoenix sylvestris, Shorea robusta, Schleihera oleosa, Syzygium cumini, Tectona grandis, Terminalia alata T. tomentosa, and T. belerica etc. The northern belt of this area has loamy sand, while the southern belt consists of sandy loam to loamy soil.

\section{Methodology}

The survey was conducted from $15^{\text {th }}$ to $31^{\text {st }}$ May and 29 mushroom samples were collected from $1^{\text {st }}$ June to $31^{\text {st }}$ Oct in 2011 and 2012. A participatory rural appraisal (PRA) survey was conducted with local people aimed at getting information largely on mycodiversity aspects. Data were obtained by combined semistructured questionnaire, participatory discussions and field observations.

Mushroom samples were photographed in their natural habitat and their morphological characters were noted. 
The samples were well dried and packed in wax paper bags with proper tag numbers. The habitat including ecological parameters viz. altitude, vegetation composition, soil type, soil $\mathrm{pH}$, soil moisture, humidity, and temperature were recorded. The paper bags were brought to the Central Department of Botany, Ttribhuvan University, for further microscopic examination.

The identification was done with the help of relevant literature (Bakshi 1971, Dickinson \& Lucas 1979, Singer
1986 and Kumar et al. 1990) and Website (biodiversity library.org; Index fungorum; Jstor.org; Mycobank.org; Scircus; tropicos.org; Agaricus in the Pacific Northwest; Boletes in the Pacific Northwest). The voucher specimens were deposited at Tribhuvan University Central Herbarium.

\section{Results and Discussion}

In the survey, 29 species of Basidiomycetes from 7 orders belonging to 18 families and 25 genera were recorded with their brief descriptions (Table 1 ).

Table 1.Mushroom species collected from Sankarnagar community forest, Rupandehi district

\begin{tabular}{|c|c|c|c|c|c|c|c|c|}
\hline $\begin{array}{l}\text { S.N } \\
0 .\end{array}$ & & $\begin{array}{l}\text { Scientific } \\
\text { rame }\end{array}$ & $\begin{array}{l}\text { Local } \\
\text { narre }\end{array}$ & Onder & Farrily & $\begin{array}{l}\text { Hoet/Substr } \\
\text { aturn }\end{array}$ & Eoology & Application \\
\hline 1 & $\begin{array}{l}10077 \\
2\end{array}$ & $\begin{array}{l}\text { Amarita } \\
\text { chepangiana } \\
\text { Tullos \& } \\
\text { Bhandary }\end{array}$ & $\begin{array}{l}\text { Salleu, } \\
\text { Kukhurr } \\
\text { a Phule } \\
\text { Chrau }\end{array}$ & Agaricales & Plutaceae & Soil & Myconthizal & Used as vegetable \\
\hline 2 & $\begin{array}{l}10077 \\
3\end{array}$ & $\begin{array}{l}\text { Amarita } \\
\text { partharina (D } \\
\text { C.) Kromb }\end{array}$ & $\begin{array}{l}\text { Bhyou } \\
\text { Chyau }\end{array}$ & Agaricales & Amaritaceae & Soil & Mycominizal & Deadly poisonous \\
\hline 3 & $\begin{array}{l}10105 \\
24\end{array}$ & $\begin{array}{l}\text { Agaricus } \\
\text { ylinicala } \\
\text { (Vittad.) Peck }\end{array}$ & $\begin{array}{l}\text { Sal } \\
\text { Chyau }\end{array}$ & Agaricales & Plutaceae & Soil & Saprophytic & not edible \\
\hline 4 & $\begin{array}{l}10071 \\
6\end{array}$ & $\begin{array}{l}\text { Auricularia } \\
\text { auricular- } \\
\text { judas (Bull.) } \\
\text { Quel. }\end{array}$ & $\begin{array}{l}\text { Kane } \\
\text { Chyau }\end{array}$ & $\begin{array}{l}\text { Auricularia } \\
\text { les }\end{array}$ & Auriculariaceae & $\begin{array}{l}\text { Log (Shorea } \\
\text { rokusta) }\end{array}$ & Saprophytic & $\begin{array}{l}\text { Edible, used to } \\
\text { prepared soup }\end{array}$ \\
\hline 5 & $\begin{array}{l}10071 \\
20\end{array}$ & $\begin{array}{l}\text { Bjerkandera } \\
\text { aduta (Willd.) } \\
\text { P. Kant. }\end{array}$ & $\begin{array}{l}\text { Kane } \\
\text { Chyau }\end{array}$ & Polyporales & Hapilopilaceae & $\begin{array}{l}\log (\text { Termin } \\
\text { alia alata) }\end{array}$ & Saprophytic & $\begin{array}{l}\text { Not edibl, used } \\
\text { as a rawr } \\
\text { strop }\end{array}$ \\
\hline 6 & $\begin{array}{l}10083 \\
29\end{array}$ & $\begin{array}{l}\text { Buchraldobol } \\
\text { Aus ligricola } \\
\text { (Kallerb.) Pilat }\end{array}$ & $\begin{array}{l}\text { Dhyabr } \\
\text { e } \\
\text { Chyau }\end{array}$ & Bolatales & Bolataceae & $\begin{array}{l}\text { Log } \\
\text { (Shorea } \\
\text { robusa) }\end{array}$ & Saprophytic & Not edible \\
\hline 7 & $\begin{array}{l}10070 \\
3\end{array}$ & $\begin{array}{l}\text { Trametes } \\
\text { hirsuta } \\
\text { (Wulfer) } \\
\text { Loyd }\end{array}$ & $\begin{array}{l}\text { Kathe } \\
\text { Chyau }\end{array}$ & Polyporales & Polyporaceae & $\begin{array}{l}\text { Log } \\
\text { (Shorea } \\
\text { robusta) }\end{array}$ & Saprophytic & \\
\hline 8 & $\begin{array}{l}10071 \\
07\end{array}$ & $\begin{array}{l}\text { Ganodam } \\
\text { lucidium P. } \\
\text { Karst. }\end{array}$ & $\begin{array}{l}\text { Dadkn } \\
\text { Chyau }\end{array}$ & Polyporales & Garoderratacex & $\begin{array}{l}\text { Trurk } \\
\text { (Bombax } \\
\text { ceiba) }\end{array}$ & Parsitic & $\begin{array}{l}\text { To rerove evil } \\
\text { spirit, for } \\
\text { used in } \\
\text { decorative } \\
\text { puroce. }\end{array}$ \\
\hline 9 & $\begin{array}{l}10071 \\
28\end{array}$ & $\begin{array}{l}\text { Gifola } \\
\text { frondosa } \\
\text { (Dicks.) Gray }\end{array}$ & $\begin{array}{l}\text { Giddha } \\
\text { Chyau }\end{array}$ & Polyporales & Meriplaceae & $\begin{array}{l}\text { Sturrp } \\
\text { (Mallotus } \\
\text { philizpinens } \\
\text { is) }\end{array}$ & Parsitic & $\begin{array}{l}\text { Used to rehef for } \\
\text { muscular pain }\end{array}$ \\
\hline 10 & $\begin{array}{l}10071 \\
5\end{array}$ & $\begin{array}{l}\text { Dacryopinax } \\
\text { spathilaria } \\
\text { (Schwein) } \\
\text { G.W.Martin }\end{array}$ & $\begin{array}{l}\text { Putali } \\
\text { Chyau }\end{array}$ & Tramellales & Dacrymycetaceae & $\begin{array}{l}\text { rotten wood } \\
\text { (Shorea } \\
\text { rokista) }\end{array}$ & Saprophytic & Not edibe \\
\hline
\end{tabular}


Nepal Journal of Science and Technology Vol. 14, No. 1 (2013) 75-80

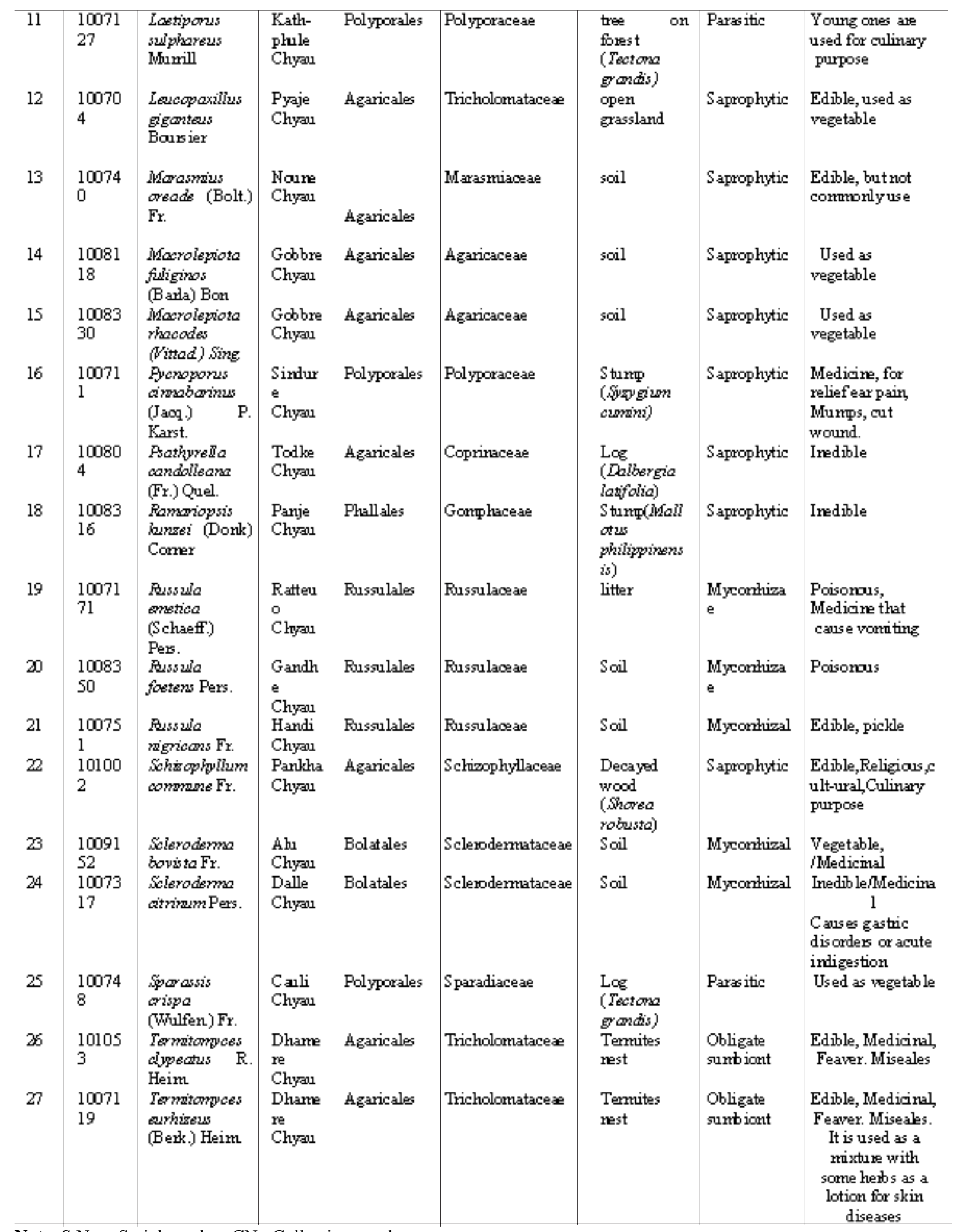

Note: S.No. =Serial number, $\mathrm{CN}=$ Collection number. 
A notable frequency of Amanita chepangiana, A. pantherina, Macrolepiota fuliginosa, M. rhacodes, Russula emetica, $R$. foetens, $R$. nigricans, Scleroderma bovista, S. citrinum, Termitomyces clypeatus, and $T$. eurhizeus, were observed. Out of the total collection, 41\% mushrooms fall under Agaricales followed by, Polyporales, Russulales, Boletales, Auriculariales, Phallales and Tremellales (fig. 2.)

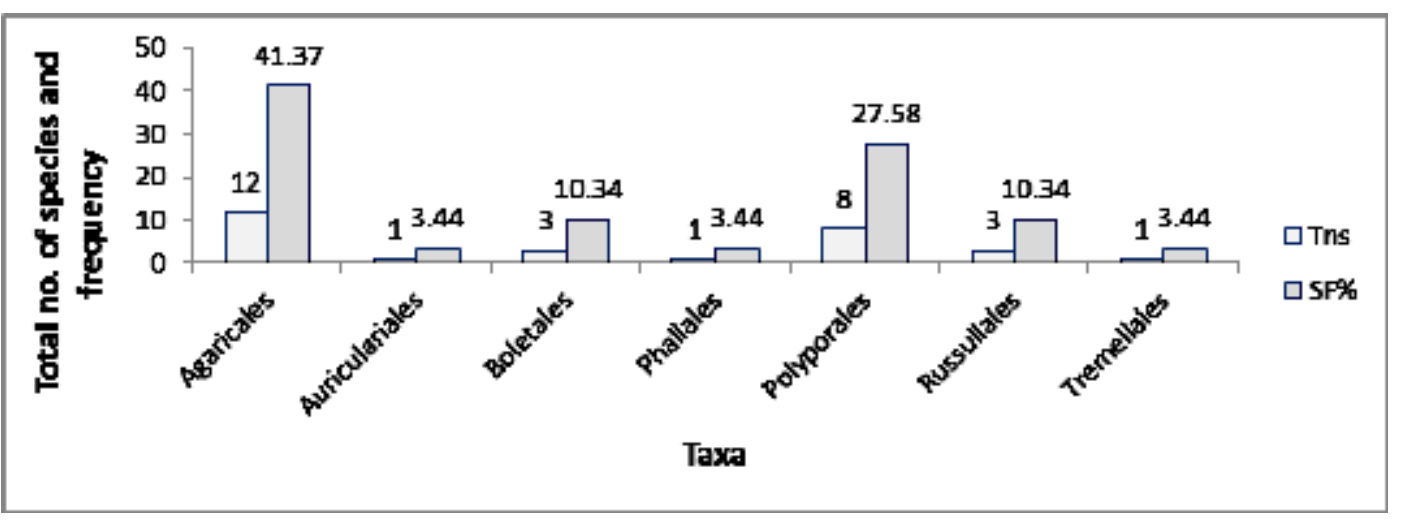

Fig. 2. Total no. of species and \% of frequency of Basidiomycotina (29 spp.)

On the basis of information collected, $91 \%$ of the collected mushrooms are used as food, $6.5 \%$ as medicine, $1.5 \%$ as taste and flavor and $1 \%$ as tonic. The food values of wild edible mushrooms are more significant in the study sites. People use these mushrooms for the remedy of different types of diseases and ailments. Their medicinal uses for the treatment of different types of diseases make them more significant for the people of the area.

The phytodiversity and ecological conditions provide a good homeland for the growth of tremendous parasitic, saprophytic and mycorrhizal fungi (Aryal et al. 2012). Wild edible mushrooms are not only an important source of food for local people but also are used as medicines. This study revealed that there were plenty of edible species of fungi in the study site. The most common among edible species were collected, sacked in bags and carried to market for selling (e.g. Macrolepiota fuliginosa, Scleroderma bovista, Termitomyces clypeatus, Termitomyces eurhizeus, Volvorella bombaycina etc).

Among 29 species, 14 are edible, 7 inedible, 3 poisonous, 4 medicinal and 1 species has religious value. Some of the the edible species viz. S. bovista, T.clypeatus and T. eurrhizus are also used for medicinal purpose. The medicinally important tropical polypore like P.cinnabarinusis is used for the remedy of infectious disease (mump), ear pain etc. Similarly, G.lucidium, a species of medicinal importance is also used as a decorative item, S.citrinum a medicinal species is also used as food. One of the exceptional case of medicinal important species $G$. frondasa was also found in the study site, though this is a temperate species. The cosmopolitan inedible species $S$. commune is sometimes used for culinary purposes in food deficit condition. This species also has religious value and is used as Sagun for better happenings in marriage ceremonies in Newar community.

During the surveys, it was found that the population of $M$. fuliginosa, $R$. nigricans, $T$. clypeatus, $T$. eurhizeus and $V$. bombycina were declining since the last two decades due to the deterioration of forest. The above mentioned notable frequencies of species were found in abundance during sample collection period. Being saprophytic, obligatory symbionts as well as part of the mycorrhizal association, these macrofungi play an important role in increasing the soil fertility in the forest by biodegradation as well as decomposition of the lignocelluloses compounds of leaf litter. The litter debris of vascular flora favors the regulation and maintenance of temperature and moisture in the soil for their macrofungi. The toxic species listed are $A$. pantherina, $R$. emetica and $R$. foetens.

The reported mushrooms are widely spread throughout the country in tropical to temperate belts. It needs extensive investigation to find out their morphological characters, species richness, distribution pattern and species diversity index. Some of the important macrofungi such as Macrolepiota, 
Scleroderma, Termitomyces, Volvorella spp., need special attention to be conserved against the threat to avoid their unmanaged and unscientific exploitation. Besides these harvesting should be done more scientifically rather than using traditional methods. The mycoelements prevailing in this area need sustainable conservation and utilization.

\section{Acknowledgements}

The author acknowledges Nepal Academy of Science and Technology for providing a Ph.D. research grant. He also acknowledges the Central Department of Botany, Tribhuvan University for providing laboratory facilities. The Institute of Agriculture and Animal Science is thanked for granting him study leave. The authors are grateful to Prof. R.D. Tiwari for his help to complete this work. Sincere thanks are extended to the local people of the study area for providing various information.

\section{References}

Adhikari, M. K. 2009. Researches on the Nepalese mycoflora. Adhikari, K.S., Alka Basti Marga, Kathmandu, Nepal. 82 pp.

Aryal, H.P., U. Budhathoki. 2012. Macro-fungi of Karhiya community forest, western Terai, Nepal. Nepalese Journal of Bioscience 2:93-97.

Bakshi, B.K. 1971. Indian Polyporaceae. Indian Council of Agriculture Resources, New Delhi.

Berkeley, M.J. 1838. Description of exotic fungi in the collection of Sir W. J. Hooker from memories and notes of J. F. Klotsch with addition and correction. Ans. Natutal History. 3: 375-401.

Christensen, M., S. Bhattarai, S. Devkota, and H. O. Larsen. 2008. Collection and use of wild edible fungi in Nepal. Eco. Bot. 62(1):12 - 23.
Dickinson, C. and J. Lucas. 1979. Encyclopedia of mushrooms. Orchid Publication, London.

DDC.2007. District Development Committee, Rupandehi: District Profile.

DFO. 2012. District Forest Office, Rupandehi: Brief Introduction and Progress Report.

De Boer, W., Folman, L.B., Summerbell, R. C. and Boddy, L. 2005. Living in a fungal world: Impact of fungi on soil bacterial niche development. FEMS Mycrobiol Review 29: 795-811.

DHM. 2010. Climatological and agrometeorological records of Nepal. Government of Nepal. Ministry of Environment, Science and Technology. Department of Hydrology and Meteorology, Kathmandu, Nepal.

Hawksworth, D.L., P.M. Kirt, B.C. Sutton and D.N. Pegler 1995. Ainsworth and Bisby's dictionary of fungi ( $8^{\text {th }}$ ed.) International Mycological Institute, CAB International, Wallingford, Oxon, U.K. 616 pp.

Kumar, A., R.P. Bhatt and T.N. Lakhanpal. 1990. The Amanitaceae of India. Bishen Sing Mahendra Pal Singh, 23- A, Dehradun, India. 160 pp.

Lloyd, C.G.1808. Mycological notes. Mycology. Cincinnati, Ohio: Lloyd Library \& Museum.

Miyamoto T, Igarashi T and Takahashi K. 2000. Lignin degrading ability of litter decomposing Basidiomycetes from Picea forest of Hokkaido. Mycosci 41: 105110.

Pandey, N. 2008. Mushroom diversity in central Nepal: An ethnomycological approach. Ph.D. dissertation. Tribhuvan University, Nepal.

Sibounnavong, P., C.D. Cynthia, S.P. Kalaw, R.G. Reyes and K. Soytong. 2008. Some species of macrofungi at Puncan, Carranglan, Nueva Ecija in the Philippines. J Agric Tech 4: 105-115.

Singer, R. 1986. The agaricales in modern taxonomy. 4th ed. Bishen Singh Mahendra Pal Singh, Dehradun, India.

Watkinson, S.C., M.C. Carlile, and G.W. Gooday, 2000. The fungi. Academic Press Limited, London, U.K. 